\title{
A Clinical Study of Kankayan Vati in the Management of Arshas (Piles)
}

\author{
Research Article
}

\section{Kanchan M.Borkar $^{{ }^{*}}$, Anant Kumar V Shekokar ${ }^{2}$, Vinod Patange $^{3}$}

1. Lecturer, 2. Reader \& HOD, Department of Shalya tantra, Ayurved College Rahuri, 3. Asst.Professor, Dept. of Dravyaguna, S C Mutha Aryangla Vaidyak Mahavidyalaya, Satara

\begin{abstract}
The purpose of present study was to evaluate the efficacy of Kankayan vati in the management of arsha (Piles). The study was carried out in 40 patients. 2 gm of Kankayan vati in the form of capsule, once in the morning was administered with takra (butter milk) as an anupan up to 21 days. The drug is given to those patients suffering from arsha and diagnosed by inspection, per-rectal examination and proctoscopy. The symptoms such as tenderness, burning pain, bleeding per-rectum, itching, anorexia, constipation \& indigestion were taken for the subjective assessment of the disease. Recovery of patients was assessed by the relief in the symptoms. According to observations and results obtained it was concluded that the treatment of arshas with Kankayan vati has given significant relief in the symptomatology of the disease.
\end{abstract}

Key words: Arsha, Piles, Kankayan vati, Anuloman, Haritaki.

\section{Introduction}

Anorectal disorder is progressively increasing in the society. Few important causes out of which number of them is sedentary life style, irregular diet, physiological disturbances like anxiety and depression and excessive consumption of junk food etc. These factors cause Mandagni (indigestion) and chronic constipation because of diet irregularities and the low fiber diet respectively and cause diseases like Arsha etc. According to Ayurveda, Mandagni is considered as a prime factor for the manifestation of many diseases like Arsha, Atisara, Grahani etc(1).

The causative factors for the formation of the Arsha, according to

\section{*Corresponding Author:}

\section{Kanchan M Borkar,}

Lecturer, Department of Shalya Tantra,

Ayurved college, Rahuri, 413706.

Maharashtra, India.

Email-drkanchanborkar@gmail.com
Ayurveda, include friction of cloths, wood, cold water, sitting of a hard object, riding on vehicle for long duration and suppression of normal urge of micturation \& defecation. Anorectal disorders are mostly embarrassing to the patient. The anal region is one of the most sensitive region in the body due to rich nerve supply. Because of this even a mild form of disorder may produce major discomfort to the patient. It has been observed that patient does not consult the physician in the initial stage of the disease because they feel ashamed due to examination of private $\operatorname{parts}(2)$.

The present work has been planned to know the efficacy of the medicinal preparation Knakayan Vati in the management of Arsha (piles).

\section{Aims and Objectives \\ To study the effect of "Kankayana Vati" in the management of Arsha (piles).}


To establish the probable mode of action of "Kankayana Vati" in the management of Arsha.

\section{Material and Methods}

The study is and open end clinical study. 40 patients suffering from the disease Arshas (piles) were selected for the study from the OPD and IPD of the Department of Shalya Tantra, Ayurveda College, Rahuri randomly.

\section{Plan of Study:-}

Prior to the commencement of the therapy in the selected patients, general information both of the patients and the disease were recorded. A complete history of the disease along with complaints was recorded as per the specially prepared proforma for the ano-rectal disorders with written consent of patient which includes the general, systemic and local examination of the patient. The local examination procedures like inspection, palpation, digital examination and proctoscopy were also performed to confirm the diagnosis.

To access the inclusion and exclusion criteria and the general well being of the patient a few laboratory investigations were also performed as follows:

\section{Laboratory investigations:}

- Blood investigations - bio-chemical and pathological

- Bleeding time and clotting time.

- Stool and urine pathological examination of microscopic and routine

\section{Selection Criteria:-}

\section{Inclusion criteria:}

- Patient presenting with Nidan, Lakshana \& Samprapti of Arsha.

- Patient between the age group of 16-60 years.

- Patient having no other complications like diabetes, carcinomatous conditions etc were selected for the study.
Exclusion criteria:

- Patients below 16 years of age and above 60 years of age are not included in the study.

- Patients suffering from chronic diseases like Carcinoma Anus \& Rectum, Ulcerative colitis, Perianal Abscess, Proctitis, etc other complications were not included

- Patient with any associated disease e.g. DM, HT, prolapsed rectum etc were excluded.

\section{Treatment Schedule}

The Selected patients were administered "Kankayana Vati" as follows: (Ref: Bhaishajya Ratnavali, Arshoadhyaya, 9/ 76). The drug is a compound preparation with the following composition.

Ingredients (3):-

$\begin{array}{ll}\text { Haritaki (bark) } & 5 \text { parts } \\ \text { Pimpali } & \text { 1 parts } \\ \text { Marich } & \text { 1 part } \\ \begin{array}{l}\text { Ajaji(shweta } \\ \text { jirak) }\end{array} & 1 \text { part } \\ \text { Pimpali mula } & 2 \text { parts } \\ \text { Chavya } & 3 \text { parts } \\ \text { Chitrak mula } & 4 \text { parts } \\ \text { Sunthi } & 5 \text { parts } \\ \text { Bhallataka } & 8 \text { parts } \\ \text { Surankanda } & 16 \text { parts } \\ \text { Yavakshar } & 2 \text { parts } \\ \text { Guda } & \text { Dwiguna (That } \\ & \text { is } 96 \text { parts) }\end{array}$

- Dose $2 \mathrm{gm}$

- Anupana Takra (Buttermilk) / Sheeta Jala

- Form of Capsule form Medicine

- Route of Oral route Administration

- Kala (Time of Pratahkala administration) (morning)

- Duration of 3 weeks Treatment

- Follow up 1 month 


\section{Follow Up Study:}

The patients of are observed weekly once and the changes have been observed and recorded. The follow up study of patients have conducted for 1 month after the completion of treatment.

\section{Criteria of Assessment:-}

The effect of treatment has been assessed on the basis of the relief of the major symptoms of the disease. This has done at a period of once in seven days. Scoring pattern was adopted to determine the relief in the cardinal symptoms as follows:

\begin{tabular}{|l|l|l|l|l|}
\hline Symptoms & $\begin{array}{l}\text { Abs } \\
\text { ent }\end{array}$ & Mild & $\begin{array}{l}\text { Mode } \\
\text { rate }\end{array}$ & $\begin{array}{l}\text { Se } \\
\text { ver } \\
\text { e }\end{array}$ \\
\hline Gudapida & 0 & 1 & 2 & 3 \\
\hline Gudadaha & 0 & 1 & 2 & 3 \\
\hline Rakta srava & 0 & 1 & 2 & 3 \\
\hline
\end{tabular}

\begin{tabular}{|l|l|l|l|l|}
\hline Kandu & 0 & 1 & 2 & 3 \\
\hline Bhransha & 0 & 1 & 2 & 3 \\
\hline $\begin{array}{l}\text { Sparsha } \\
\text { asahatwa }\end{array}$ & 0 & 1 & 2 & 3 \\
\hline Shotha & 0 & 1 & 2 & 3 \\
\hline $\begin{array}{l}\text { Mucous } \\
\text { discharge }\end{array}$ & 0 & 1 & 2 & 3 \\
\hline Vibandha & 0 & 1 & 2 & 3 \\
\hline $\begin{array}{l}\text { Agni } \\
\text { vaishamya }\end{array}$ & 0 & 1 & 2 & 3 \\
\hline Atopa & 0 & 1 & 2 & 3 \\
\hline Pandu & 0 & 1 & 2 & 3 \\
\hline
\end{tabular}

Result obtained from the study will be assessed in the terms of following

\begin{tabular}{|ll|l|l|}
\hline$\bullet$ & Incurable & - & Below $25 \%$ \\
\hline$\bullet$ & Improved & - & $25 \%$ to $50 \%$ \\
\hline$\bullet$ & $\begin{array}{l}\text { Markedly } \\
\text { improved }\end{array}$ & - & $51 \%$ to $75 \%$ \\
\hline$\bullet$ & Cured & - & More than $75 \%$ \\
\hline
\end{tabular}

\section{Observations and Results:}

The above said subjective parameters of the study were recorded without any bias and the obtained results were tabulated and the results are assessed statistically and are expressed in terms of ' $Z$ ' value and ' $p$ ' values to show the significance of the study.

The results of the study are as follows:

Table No 1: Effect of Therapy on Cardinal Symptoms of Arshas

\begin{tabular}{|c|c|c|c|c|c|c|c|c|c|}
\hline \multirow{2}{*}{$\begin{array}{l}\text { Cardinal } \\
\text { Symptoms }\end{array}$} & \multirow{2}{*}{$\mathbf{n}$} & \multicolumn{2}{|c|}{ Mean } & \multirow{2}{*}{ SD } & \multirow{2}{*}{ SE } & \multirow{2}{*}{$\mathbf{Z}$} & \multirow{2}{*}{$\begin{array}{l}\text { 'p' } \\
\text { value }\end{array}$} & \multirow[t]{2}{*}{ Result } & \multirow{2}{*}{$\begin{array}{l}\% \text { Of } \\
\text { Relief }\end{array}$} \\
\hline & & B.T. & A.T. & & & & & & \\
\hline Gudapida & 33 & 67 & 03 & 0.7533 & 0.1312 & 14.77 & $>0.01$ & $\begin{array}{l}\text { Highly } \\
\text { significant }\end{array}$ & 95.52 \\
\hline Gudadaha & 33 & 78 & 07 & 0.8211 & 0.1430 & 15.03 & $>0.01$ & $\begin{array}{l}\text { Highly } \\
\text { significant }\end{array}$ & 91.02 \\
\hline Rakta srava & 32 & 77 & 05 & 0.8291 & 0.1465 & 15.35 & $>0.01$ & $\begin{array}{l}\text { Highly } \\
\text { significant }\end{array}$ & 93.50 \\
\hline Kandu & 13 & 27 & 07 & 0.4992 & 0.1384 & 11.05 & $>0.01$ & $\begin{array}{l}\text { Highly } \\
\text { significant }\end{array}$ & 74.07 \\
\hline Bhransha & 20 & 38 & 32 & 0.4582 & 0.1024 & 2.42 & $<0.01$ & $\begin{array}{l}\text { Not } \\
\text { signoficant }\end{array}$ & 15.78 \\
\hline Sparshasahatwa & 36 & 87 & 07 & 0.6450 & 0.1075 & 23.51 & $>0.01$ & $\begin{array}{l}\text { Highly } \\
\text { significant }\end{array}$ & 91.95 \\
\hline Shotha & 36 & 79 & 06 & 1.5272 & 0.2545 & 7.96 & $>0.01$ & $\begin{array}{l}\text { Highly } \\
\text { significant }\end{array}$ & 92.40 \\
\hline Mucous & 09 & 13 & 02 & 0.4149 & 0.1383 & 8.89 & $>0.01$ & Highly & 84.61 \\
\hline
\end{tabular}




\begin{tabular}{|l|l|l|l|l|l|l|l|l|l|}
\hline discharge & & & & & & & & significant & \\
\hline Vibandha & 40 & 106 & 10 & 0.8366 & 0.1322 & 18.91 & $>0.01$ & $\begin{array}{l}\text { Highly } \\
\text { significant }\end{array}$ & 90.56 \\
\hline Agnivaishamya & 40 & 114 & 10 & 0.6633 & 0.1048 & 24.80 & $>0.01$ & $\begin{array}{l}\text { Highly } \\
\text { significant }\end{array}$ & 91.22 \\
\hline Atopa & 36 & 88 & 05 & 0.5682 & 0.0947 & 24.28 & $>0.01$ & $\begin{array}{l}\text { Highly } \\
\text { significant }\end{array}$ & 94.31 \\
\hline Pandu & 06 & 11 & 07 & 0.7452 & 0.3042 & 1.97 & $<0.01$ & $\begin{array}{l}\text { Not } \\
\text { significant }\end{array}$ & 36.36 \\
\hline
\end{tabular}

Table No 2: Overall effect of Therapy.

\begin{tabular}{|l|l|l|}
\hline Effect & No of Pt & Percentage \\
\hline Cured & 37 & $92.50 \%$ \\
\hline Markedly Improved & 03 & $7.5 \%$ \\
\hline Improved & - & - \\
\hline Unchanged & - & - \\
\hline
\end{tabular}

\section{Discussion}

Kankayana vati have revealed to have potential of Shula prashamana and disease modifying effect with the added advantage of being free from side effects, gastric irritation, and ulcerogenic activity.

\section{Discussion of result according to Degree of piles:-}

The result obtained among 26 patients, 10 patients $(38.46 \%)$ got cured $\&$ 02 patient $(7.69 \%)$ got markedly improved in Third degree internal piles, 08 patients $(30.76 \%)$ had got cured in First degree internal piles while 05 patients $(19.23 \%)$ got cured \& 01 patients $(3.84 \%)$ got markedly improved in second degree internal piles. This data shows that Kankayana vati formulation has potency to cure upto third degree internal piles.

Almost all the symptoms studied have shown highly significant results and almost above $90 \%$ of the relief in the symptoms except for the symptoms like pandu and bramsha.

\section{Probable mode of action of Kanakayana vati}

According to Bhaishajya ratnavali and Yogaratnakara Kankayana vati is mentioned under Arshorogadhikar.
In Kankayana vati formulation, the ingredients are- Pippali, Haritaki, Pippalimula, Suntha, Chavya, Chitrak, Surankanda, Ajaii, Bhallatak, Yavakshar, etc. Almost all of these drugs are having the property of Deepan, Pachana, Vatanulomana, ushna guna hence will have shulaprashamana or the pain relieving activity and are said to be the best appetizers. Drugs like Haritaki, help to relieve the constipation and decrease the pressure on the pile masses. Drugs like Pimpalimula, Sunthi, Chavya, Chitrak, Surankanda, are specifically indicated for the treatment of Arshas, according to Bhavaprakash Nighantu(4).

Surankand has special effect (Prabhav) as Arshoghna(5). So it is the pathya in all Arsha. As it is kashaya rasapradhana, it is useful to stop bleeding in Raktarsha, because of ushna and tikshna guna. Also ushna, tikshna guna helps rakta dhatu to flow in regular manner without any congestion at veins and hence shotha (inflammation) decreases and size of pile mass seems to be decreased as ushna guna dilates the channel of raktavaha strotas. Most of the ingredients of Kankayana vati formulation are katu rasapradhana and they help in reducing the blood clotting or accumulation as they are said to be having action as "Shonit 
Sanghata Bhinnati". It is stated that Arsha is the congestion of veins and katu rasa dissolve the congestion.

Yavakshar also has the property of lekhana, mild laxative, antacid, deepana and raktashodhana(6). So it is also useful in samprapti vighatana of Arsha.

The root cause for Arsha is Mandagni, due to which production of ama increases and such continuous production of ama leads to malasanchaya. This large quantity of mala is loaded in colon for long duration. Absorption of fluids from faeces occurs in large quantity resulting in hard stool passage. To pass such hard stool, patients undergoes straining (pravahana) during defaecation, finally resulting in dilated rectal plexus and mamsankur (Arsha) uttpati occurs. So from above pathological process most of the Ayurvedic texts gives more concentration for deepana (increasing jatharagni) and digestion of ama i.e. pachana chikitsa respectively effects on mandagni and ama. Charakacharya mentioned most of the ingredients in deepaniya, Arshoghna and shulaprashamana gana while Sushrutacharya explained in pippalyadi gana which acts as deepana, pachana, vatanuloman, shulaprashaman, kaphaghna. Thus the Chikitsa with Kankayan vati disturbs pathological process of Arsha and ultimately patients get relief from signs and symptoms of Arsha.

\section{Conclusion}

From the above study it can be concluded that the drug Kankayan vati proves to be one of the best drugs in the management of Arsha. It helps in relieving the symptoms of the Arshas like pain, bleeding etc. As the study was conducted only in a limited set of conditions, the results must to be evaluated in a large population to prove its efficacy.

\section{References:}

1. Sharma.P.V. Sushruta Samhita of Acharya Sushruta with Dalhana commentary, Chaukhmabha, $4^{\text {th }}$ edition, 1980.

2. K.K.Sijoria and Pravin kumar, Diagnosis and Managament of Anorectal Diseases, $1^{\text {st }}$ Edition, Delhi, Choukhamba, 2002.

3. Ambikadatta Shastry, Bhaishajyaratnavali, $15^{\text {th }}$ edition, Varanasi, Choukhamba Sanskrut Bhavan, 2002, $218 \mathrm{p}$

4. Brahmashankar shastry, Bhavaprakash Nighantu, $6^{\text {th }}$ edition, Varanasi, Choukhamba Sanskrut Bhavan, 1994

5. Brahmashankar shastry, Bhavaprakash Nighantu, $6^{\text {th }}$ edition Varanasi, Choukhamba Sanskrut Bhavan, 1994, 692p

6. Brahmashankar shastry,Bhavaprakash Nighantu,6,Varanasi,Choukhamba Sanskrut Bhavan,1994,164p 